\title{
Biological Control of Oomycetous Plant Pathogens: A Review
}

\author{
Anupama Shrestha ${ }^{1}$, Sung Hee Park ${ }^{4}$, Bhushan Shrestha ${ }^{3}$, Kangmin Kim ${ }^{1,2}$, Jong Chan \\ Chae $^{1,2}$, and Kui Jae Lee ${ }^{1,2}$ \\ ${ }^{1}$ Division of Biotechnology, Chonbuk National University, Iksan 570-752, Korea \\ ${ }^{2}$ Advanced Institute of Environment and Bioscience, Chonbuk National University, \\ Iksan 570-752, Korea \\ ${ }^{3}$ Institute of Life Science and Biotechnology, Sungkyunkwan University, \\ Suwon 440-746, Korea \\ ${ }^{4}$ Department of Rehabilitation Medicine, School of Medicine, Chonbuk National University, \\ Jeonju, 561-756, Korea \\ e-mail:leekj@jbnu.ac.kr
}

\begin{abstract}
Oomycetes are generally known as water molds, and include diverse plant pathogenic organisms. In this review, we summarized plant diseases mainly caused by oomycetes and highlighted ongoing trends in controlling and managing these pathogens using eco-friendly ways.
\end{abstract}

Key words: antagonistic microorganisms, biological control, oomycet

\section{Introduction}

Oomycetes, commonly known as water molds (Winter 1880) are detrimental plant pathogens infecting a wide range of host plants such as native weeds, ornamental plants, and trees (Erwin \& Ribeiro 1996, Margulis \& Schwartz 2000, van West et al. 2003, Sanogo \& Ji 2012). The pathogenicity of oomycetes is rendered by their spore production, development of infecting structures, and dispersal of spores (Endo \& Colt 1974, Kramer et al. 1997). In molecular aspects, effector proteins recognized by signature amino acid motifs RxLR (arginine, any amino acid, leucine, arginine), and dEER (a string of acidic amino acids followed by arginine) are known to facilitate the oomycetes virulence in host plant (Kale \& Tyler 2011, Tyler 2011).

Oomycetes are being controlled by numerous approaches which include clean nursery stock, use of resistant varieties, chemical, physical, and systemic fungicides. Biological control agents (BCAs) are also used to suppress oomycetes and their related diseases (Pal \& Gardener 2006, Lee et al. 2005, Sang \& Kim 2012). Aside from these, however, various Pythiumand Phytophthora-causing diseases exhibited the resistance to BCAs such as propamocarb, mefenoxam, and metalaxyl, no longer (Titone et al. 2009, Moorman \& Kim 2004, Parra et al. 2001). Therefore, development of more advanced and efficient biological control is of utmost necessity for future success to control oomycetes. This mini review summarized major diseases caused by oomycetous pathogens, efficient BCAs against oomycetous diseases, and their relevant mechanisms.

\section{Major diseases caused by oomycetes}

The plant pathogenic oomycetes contains many taxa and exhibit remarkably diverse lifestyles ranging from obligate biotroph to necrotroph (Agrios 2011). General life cycle of these pathogens can be exemplified by Phytophthora capsici (Fig 1a). Few representative disease symptoms caused by them are shown in (Fig 1b). The diseases caused by major genera such as Phytophthora, Pythium, Peronospora, Albugo, and Aphanomyces are summarized in (Table 1). Species of Pythium, Phytophthora, Aphanomyces and Rhizoctonia, etc. are known to cause damping-off disease (Agrios 2011). Albugo candida causes white rust on Erysimum crassicaule (Mirzaee et al. 2009). 
Soil borne Phytophthora and Pythium spp. are also widespread and cause major losses on crops of soybeans (Schmitthenner 1985) and avocados (Cohen 1981, Darvas et al. 1984). In addition, Phytophthora and Pythium spp. were responsible for many pre- and post-harvest problems on fruits and vegetables, including brown rot of citrus (Cohen 1981a, b, 1982, Gutter 1983), and black pod of cocoa (McGregor 1983, 1984). Recently, new diseases are emerging caused by these oomycetes; for example, severe rotting and blight of seedlings of soybean (Tomioka et al. 2013), root rot disease of legumes (Gaulin et al. 2007), etc. New species were also reported in many crops: Pythium solare (wilt and death of adult plants of
Phaseolus vulgaris) (de Cock et al. 2008), Pythium myriotylum (root and crown necrosis) (Serrano et al. 2008), Phytophthora bisheria (raspberry, rose, and strawberry diseases) (Abad et al. 2008), Pustula sp. (sunflower white rust) (Rost \& Thines 2012), Pythium echinogynum (severe "damping-off pathogen" to tomato and cucumber seedlings) (Balghouthi et al. 2013), etc. Some other oomycetes such as Phytophthora gallica (Jung \& Nechwatal 2008), Pythium indigoferae, and Pythium irregulare (Souli et al. 2011) caused diseases in oak and apple trees, respectively.

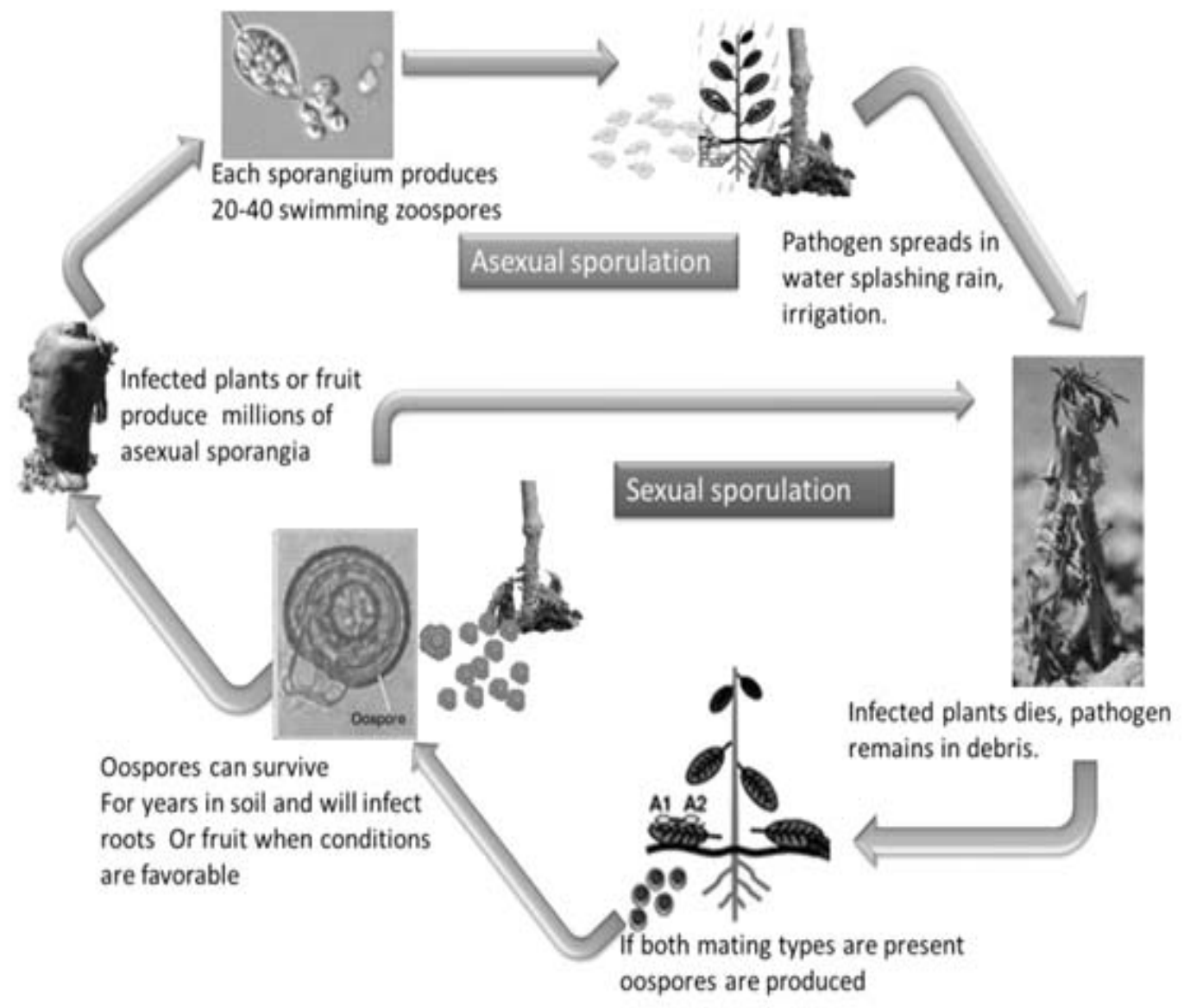

Fig. 1a. Diagram depicting the life cycle of Phytopthora capsici.

Life cycle figure was provided by C.D. Smart, Cornell University, with some modifications.

Oospores; Reproduced by permission, from Gallup, C. A., Sullivan, M. J., and Shew, H. D. 2006. Black shank of tobacco. The Plant Health Instructor. DOI: 10.1094/PHI-I-2006-0717-01.

Photo courtesy Zoospores: Fred Brooks, University of Hawaii at Manoa, Bugwood.org. 

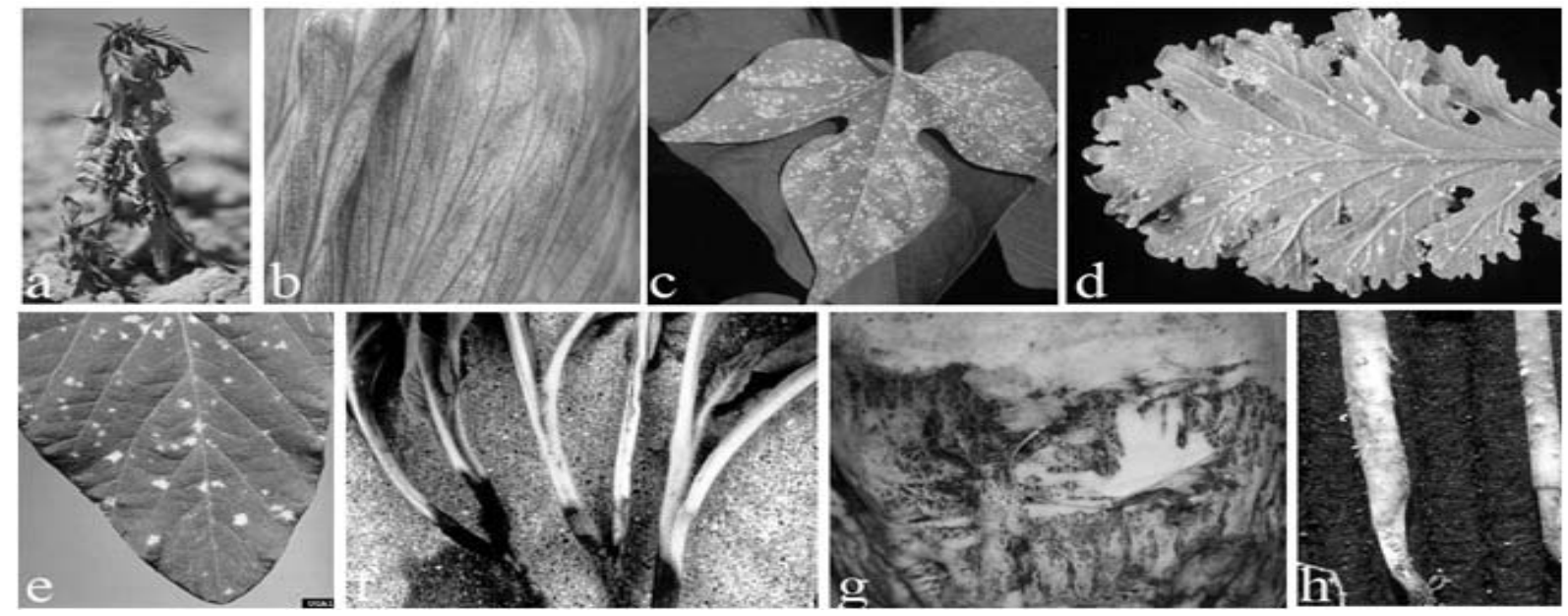

Fig. 1b. Representative photographs of some disease symptoms caused by oomycetes:

a) Symptoms of Phytopthora blight on pepper plant with characteristic wilting due to Phytopthora capsici leonian, b) Downy mildew on lettuce plant by Bremia lactucae, c) White rust on morning glory leaf with heavy sporulation of white rust caused by Albugo ipomoe panduratae, d) White rust on mustard with white rust pustules on the leaf underside due to Albugo candida, e) Downy mildew on soyabean caused by Peronospora manshurica, f ) Damping off of tobacco with characteristic large and wet lesions caused by Pythium sp. pringsh., g) Damping off characterized by root rot external symptoms on mature beet, superficial scaring caused by Aphanomyces cochlioides, and h) Damping off of common bean caused by Pythium spp.

Photo courtesy; a, b, c, d; Gerald Holmes, Valent USA Corporation, Bugwood.org.

e; Clemson University, USDA Cooperative Extension Slides Series, Bugwood.org.

f; R. J. Reynolds, Tobacco Company Slide Set, Bugwood.org.

g; Oliver T. Neher, The Amalgamated Sugar Company, Bugwood.org.

h; Howard F. Schwartz, Colorado State University, Bugwood.org.

Table 1. Important plant pathogenic oomycetes and diseases caused by them

\begin{tabular}{|c|c|c|}
\hline Pathogen & Disease caused & References \\
\hline \multirow[t]{5}{*}{ Phytopthora species } & Root rot pathogen of soybean & Tyler 2007, Souli et al. 2011, Sang et al. 2013 \\
\hline & Root and crown necrosis of bean & Abad et al. 2008 \\
\hline & Damping off disease & Agrios 2011 \\
\hline & Root rot on ginseng & Sang et al. 2006 \\
\hline & Damping-off, root-rot & $\begin{array}{l}\text { Cohen 1981a, Cohen 1981b, Cohen } 1982 \\
\text { Van West et al. 2003, Schmitthenner 1985, } \\
\text { Cohen 1981a }\end{array}$ \\
\hline \multirow{3}{*}{ Pythium species } & $\begin{array}{l}\text { damping-off pathogen" to tomato and } \\
\text { cucumber seedlings }\end{array}$ & Balghouthi et al. 2013 \\
\hline & Root rot disease of legumes & $\begin{array}{l}\text { Cohen } 1981 \text { b, Cohen } 1982 \text {, Gutter } 1983 \text {, } \\
\text { de Cock et al. } 2008 \text {, Serrano et al. } 2008 \text {, } \\
\text { Balghouthi et al. } 2012\end{array}$ \\
\hline & & Souli et al. 2011 \\
\hline $\begin{array}{l}\text { Peronospora Bremia, } \\
\text { Plasmopara }\end{array}$ & Various downy mildews & Agrios 2011 \\
\hline \multirow[t]{2}{*}{ Albugo species } & White blister & Abbasi \& Mohammadi, 2009 \\
\hline & Sunflower white rust & Rost \& Thines, 2012 \\
\hline Aphanomyces & Damping off disease & Agrios 2011, Gaulin et al. 2007 \\
\hline
\end{tabular}


Nepal Journal of Science and Technology Vol. 15, No.1 (2014) 157-166

\section{Biological control of oomycetes and mechanisms involved}

Microorganisms from different sources such as rhizosphere and phylloshere can potentially reveal biological control effects against different plant pathogenic oomycetes. In mechanistic basis, these microorganisms control the target pathogens by antibiotic production, root colonization, nutrient competition, induced systemic resistance, plant growth promotion, mutualism, mycoparasitism, and predation. Some of the common bacteria, fungi, and actinomycetes against oomyceteous pathogens were summarized (Table 2). The most effective bacterial isolates were Pseudomonas, Bacillus, Lysobacter, Enterbacter, and Paenibacillus. Fungi such as Trichoderma, endophytic Fusarium, and Ganoderma spp. also controlled oomycetes. Moreover, about $9 \%$ of the total number of isolated bacteria identified as Firmicutes, $\alpha$-Proteobacteria, $\gamma$-Proteobacteria and Actinomycetes exhibited anti-oomycetic activity (Bibi et al.2012).

Table 2. Biological control agent (BCA) and some commercial microbial inoculants for control of plant disease

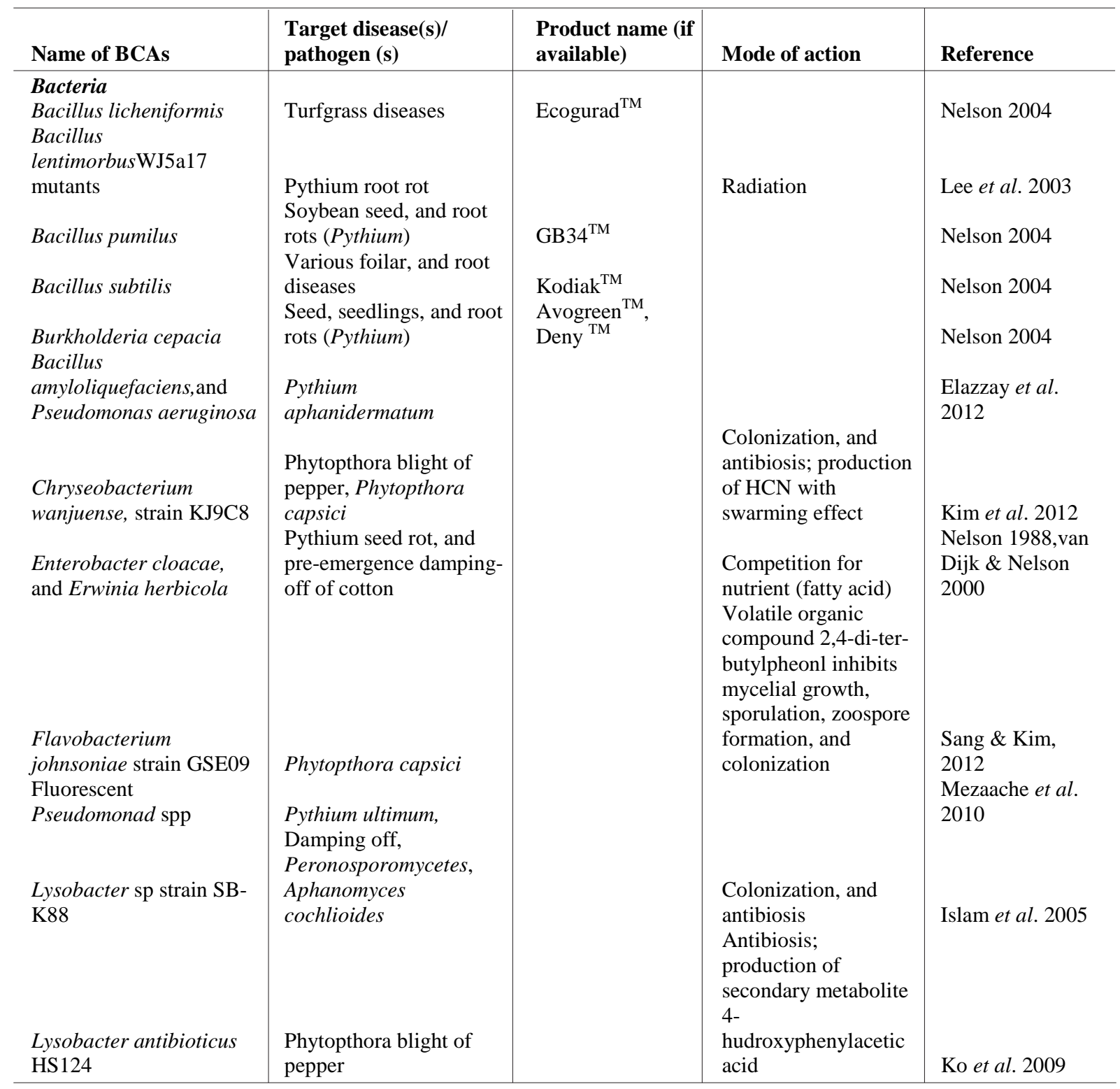


Anupama Shrestha et al./Biological Control of Oomycetous....

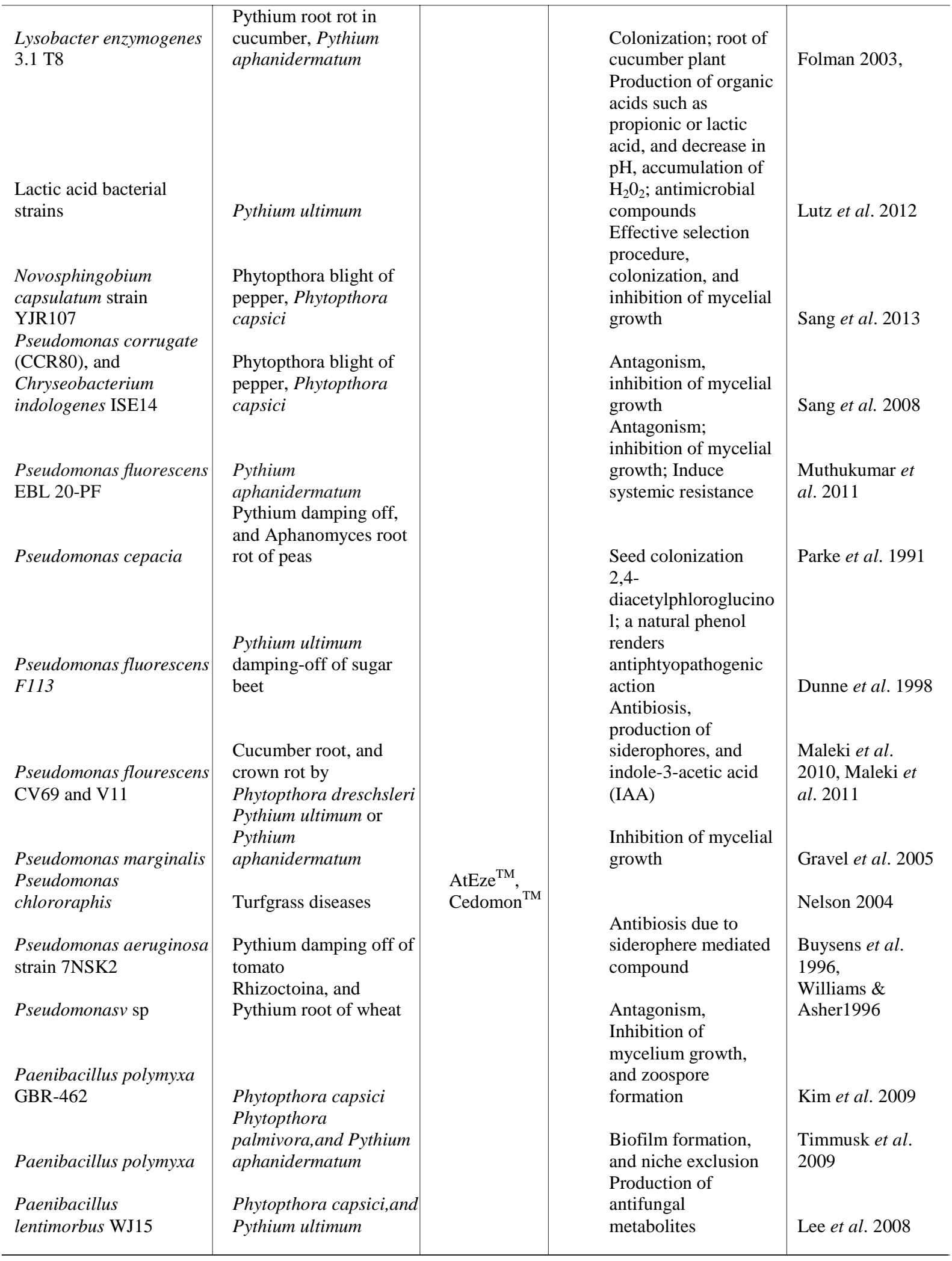


Nepal Journal of Science and Technology Vol. 15, No.1 (2014) 157-166

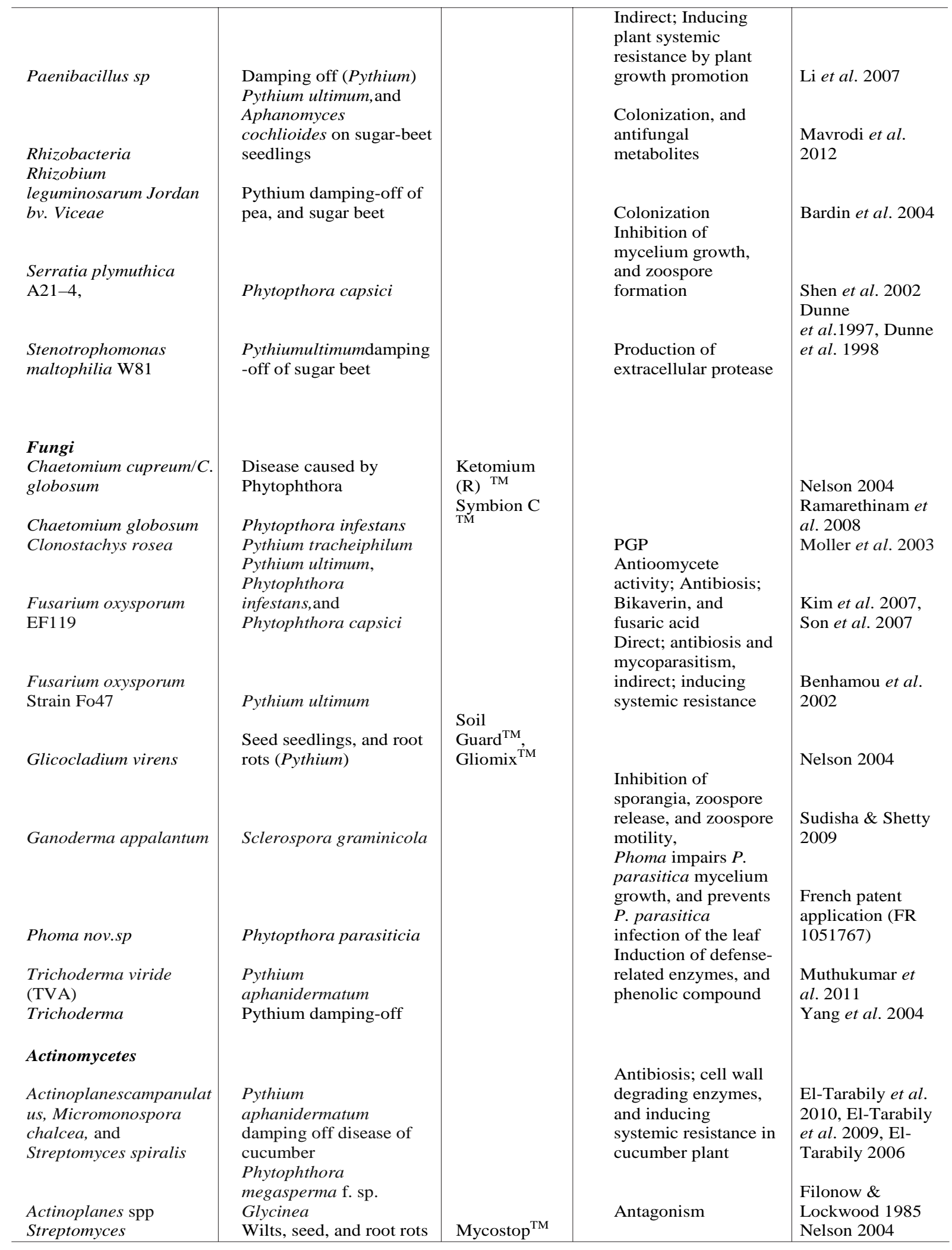


Mechanisms of anti-oomycetic activity are mainly due to colonization, antibiotic production, hyphal lysis, sporangium abortion, oospore parasitism and siderophore production (Buysens et al. 1996, Broadbent et al. 1971, Drapeau et al. 1973, Honor \& Tsao 1973, Broadbent \& Baker 1974, Wynn \& Epton 1979). Colonization of bacteria (e.g. Enterobacter cloacae) resulted in a competitive exclusion of nutrients from Pythium, Phytopthora capsici, and Phytophthora cactorum (Nelson 1988, Sang et al. 2007, Sang et al. 2006). Various antibiotics and lytic enzymes produced by microorganisms revealed antagonism against oomycetes (Dunne et al. 1997, Lee et al. 2003, Lee et al. 2008, Timmusk et al. 2009, Muthukumar et al. 2011). Recently, Streptomyces producing chitinase, ß-1, 3-glucanase, lipase and protease showed direct lysis of Phytophthora capsici hyphae (Nguyen et al. 2012). In addition, Pseudomonas ûuorescens and Serratia plymuthi showed the antagonisms to Pythium aphanidermatum and Phytophthora capsici (Muthukumar et al. 2011, Shen et al. 2002). The compounds originated from Streptomyces koyangensis and Ganoderma appalantum restricted the growth of oomycetes (Lee et al. 2005, Sudisha \& Shetty 2009).

On the other hand, various BCAs were suggested to control oomycetes by modulating the induced systemic resistance (ISR) of host plants either directly or through volatile organic compounds produced by them (Benhamou et al. 2002, Sang \& Kim 2012). Most of the BCAs reported are able to suppress more than one pathogen; however, some of them were pathogen specific and even some were host-specific showing selective influence of BCAs (Maurhofer et al. 1994, Van Dijk \& Nelson 2000, Mavrodi et al. 2012, Sang et al. 2013). Combination treatment of bacteria-fungi or bacteriabacteria are also effective to control oomycetes (Dunne et al. 1998, Muthukumar et al. 2011).

\section{Future perspectives}

Development of anti-oomycetic BCAs is very important and utmost necessity for managing oomycetic diseases as it is considered as an alternative or a supplemental way of reducing the use of chemicals in agriculture (De weger et al. 1995, Gerhardson 2002). More researches should be carried out to elucidate the mechanism involved in the microorganism-pathogen interaction and to identify the novel efficient BCAs in future to establish sustainable BCAs against oomycetous diseases. Finally, we can conclude that different biological control approaches summarized in this review can shed light on future directions in developing and choosing different biological control agents against oomycetes.

\section{Acknowledgements}

This work was carried out with the support of Cooperative Research Program for Agriculture Science \& Technology Development (PJ009411) RDA, Korea, the National Research Foundation of Korea (NRF) grant funded by the Korean government (MEST) (No2011-0020202), and the research funds of Chonbuk National University.

\section{References}

Abad, Z.G., J.A. Abad, M.D. Coffey, P.V. Oudemans, W.A. Man in't Veld, H. de Gruyter, J. Cunnington and F.J.Louws. 2008. Phytophthora bisheria sp. nov., a new species identified in isolates from the Rosaceous raspberry, rose and strawberry in three continents. Mycologia 100: 99-110.

Agrios, G.N.and J.Beckerman. 2011. Plant pathology. New York: Acad. Press.

Balghouthi, A., R. Jonathan, S. Gognies, A. Mliki and A. Belarbi. 2013. A new species, Pythium echinogynum, causing severe damping-off of tomato seedlings, isolated from Tunisia, France, and India: morphology, pathology, and biological control. Annals of Microbiology 63: 253-258.

Bardin, S.D., H.C. Huang, J. Pinto, E.J. Amundsen and R.S. Erickson. 2004. Biological control of Pythium dampingoff of pea and sugar beet by Rhizobium leguminosarum bv. viceae. Canadian Journal of Botany 82: 291-296.

Benhamou, N., C. Garand and A. Goulet. 2002. Ability of nonpathogenic Fusarium oxysporum strain Fo47 to induce resistance against Pythium ultimum infection in cucumber. Applied and Environmental Microbiology 68: 4044-4060.

Bibi, F., M. Yasir, G.C. Song, S.Y. Lee and Y.R. Chung. 2012. Diversity and characterization of endophytic bacteria associated with tidal flat plants and their antagonistic effects on oomycetous plant pathogens. Plant Pathology Journal 28: 20-31.

Broadbent, P., K.F. Baeker and Y. Waterworth. 1971. Bacteria and actinomycetes antagonistic to fungal root pathogens in Australian soils. Australian Journal of Biological Science 24: 925-944.

Broadbent, P. and K.F. Baeker. 1974. Behaviour of Phytopthora cinnamomi in soils suppressive and conducive to root rot. Australian Journal of Agricultural Research 25: 121137.

Buysens, S., K. Heungens, J. Poppe and M. Hofte. 1996. Involvement of pyochelin and pyoverdin in suppression of Pythium-induced damping-off of tomato by Pseudomonas aeruginosa 7NSK2. Applied and Environmental Microbiology 62: 865-871.

Cohen, E. 1981a. Metalaxyl for postharvest control of brown rot of citrus fruit. Plant Disease 65: 672-675. 
Cohen, E. 1981b. Post harvest control of Phytophthora citrophthora with metalaxyl, and its relation to other fungi systemic fungicides 333 pathogenic to citrus fruit. Proceedings International Society of Citricult 2: 793-796.

Cohen, E. 1982. Prevention of spread and contact infection of brown rot disease in citrus fruit by metalaxyl postharvest treatment. Phytopathologische Zeitschrift 103: $120-125$.

Darvas, J.M., J.C. Toenen and D.L. Milne. 1984. Control of avocado root rot by trunk injection with phosethylAl. Plant Disease 68: 691-693.

De Cock, A.W., C.A. Lévesque, J.M. Melero-Vara, Y. Serrano, M.L. Guirado and J. Gómez. 2008. Pythium solare sp. nov., a new pathogen of green beans in Spain. Mycological Research 112: 1115-1121.

De weger, L.A., A.J. van der Bij, L.C. Dekkers, M. Simons, C.A. Wijffelman and B. J.J. Lugtenberg. 1995. Colonization of the rhizosphere of crop plants by plant beneficial Pseudomonads. FEMS Microbiology Ecology 17: 221-227.

Drapeau, R.F., J.A. Fortin and C. Gagnon. 1973. Antifungal activity of Rhizobium. Canadian Journal of Botany 51: 681-682.

Dunne, C., J.J. Crowley, Y. Moenne-Loccoz, D.N. Dowling, S. Bruijn and F. O'Gara. 1997. Biological control of Pythium ultimum by Stenotrophomonas maltophilia W81 is mediated by an extracellular proteolytic activity. Microbiology 143: 3921-3931.

Dunne, C., Y. Moenne-Loccoz, J. McCarthy, P. Higgins, J. Powell, D.N. Dowling and F. O'Gara. 1998. Combining proteolytic and phloroglycinol-producing bacteria for improved biocontrol of Pythium-mediated dampingoff of sugar beet. Plant Pathology 47: 299-307.

El -Tarabily, K.A. 2006. Rhizosphere-competent isolates of streptomycete and non-streptomycete actinomycetes capable of producing cell-wall degrading enzymes to control Pythium aphanidermatum damping-off disease of cucumber. Canadian Journal of Botany 84: 211-222.

El-Tarabily, K.A., G.E.St.J. Hardy and K. Sivasithamparam. 2010. Performance of three endophytic actinomycetes in relation to plant growth promotion and biological control of Pythium aphanidermatum, a pathogen of cucumber under commercial field production conditions in the United Arab Emirates. European Journal of Plant Pathology 128: 527-539.

El-Tarabily, K.A., G.E.St.J. Hardy, K. Sivasithamparam, A.M. Hussein and I.D. Kurtboke. 1997. The potential for the biological control of cavity spot disease of carrots caused by Pythiumcoloratum by streptomycete and nonstreptomycete actinomycetes in Western Australia. New Phytologist 137: 495-507.

El-Tarabily, K.A., A.H. Nassar, G.E.St.J. Hardy and K. Sivasithamparam. 2009. Plant growth promotion and biological control of Pythium aphanidermatum, a pathogen of cucumber, by endophytic actinomycetes. Journal of Applied Microbiology 106: 13-26.

Endo, R.M. and W.M. Colt. 1974. Anatomy, cytology, and physiology of infection by Pythium. Proceedings of the American Phytopathological Society 1: 215-222.

Erwin, D.C. and O.K. Ribeiro. 1996. Proc American Phytopathol Soc Phytophthora Diseases Worldwide.

Filonow, A.B. and J.L. Lockwood. 1985. Evaluation of several actinomycetes and the fungus Hyphochytrium catenoides as biocontrol agents for Phytophthora root rot of soybean. Plant Disease 69: 1033-1036.

Folman, L.B. 2003. Biological control of Pythium aphanidermatum in soilless systems: selection of biocontrol agents and modes of action. $\mathrm{PhD}$ Thesis. University of Leiden, The Netherlands, pp 123-143.

Gaulin, E., C. Jacquet, A. Bottin and B. Dumas. 2007. Root rot disease of legumes caused by Aphanomyces euteiches. Molecular Plant Pathology 8: 539-548.

Gerhardson, B. 2002. Biological substitutes for pesticides. Trends in Biotechnology 20: 338-343.

Gravel, V., C. Martinez, H. Antoun and R.J. Twedell. 2005. Antagonist microorganisms with the ability to control Pythium damping-off of tomato seeds in rockwool. Biocontrol 50: 771-786.

Gutter, Y. 1983. Supplementary antimold activity of phosethyl AI, a new brown rot fungicide for citrus fruits. Phytopathologische Zeitschrift 30: 1-8.

Honor, R.C. and P.H. Tsao. 1973. Lysis of Phytopthora parasitica oospores in soil. In : 2nd Int Congr. Plant Pathol. Am. Phytopathol . Soc. St. Paul., MN.

Islam, M.T., Y. Hashidoko, A. Deora, T. Ito and S. Tahara. 2005. Suppression of damping-off disease in host plants by the rhizoplane bacterium Lysobacter sp. strain SB-K88 is linked to plant colonization and antibiosis against soilborne Peronosporomycetes. Applied and Environmental Microbiology 71: 37863796.

Jung, T. and J. Nechwatal. 2008. Phytophthora gallica sp. nov., a new species from rhizosphere soil of declining oak and reed stands in France and Germany. Mycological Research 112: 1195-1205.

Kale, S.D. and B.M. Tyler. 2011. Entry of oomycete and fungal effectors into plant and animal cells. Cell Microbiology 13: 1839-1848.

Kim, H.S., M.K. Sang, H.W. Jung, Y.C. Jeun, I.S. Myung and K.D. Kim. 2012. Identification and characterization of Chryseobacterium wanjuense strain KJ9C8 as a biocontrol agent of phytopthora blight of pepper. Crop Protection 32: 129-137.

Kim, H.Y., G.J. Choi, H.B. Lee, S.W. Lee, H.K. Lim, K.S. Jang, S.W. Son, S.O. Lee, K.Y. Cho, N.D. Sung and J.C. Kim. 2007. Some fungal endophytes from vegetable crops and their anti-oomycete activities against tomato late blight. Letters in Applied Microbiology 44:332-337. 
Anupama Shrestha et al./Biological Control of Oomycetous....

Kim, S.G., Z. Khan, Y.H. Jeon and Y.H. Kim. 2009. Inhibitory effect of Paenibacillus polymyxa GBR-462 on Phytophthora capsici causing Phytophthora blight in chili pepper. Journal of Phytopathology 157: 329337.

Ko, H.S., R.D. Jin, H.B. Krishnan, S.B. Lee and K.Y. Kim. 2009. Biocontrol ability of Lysobacter antibioticus HS124 against Phytophthora blight is mediated by the production of 4-hydroxyphenylacetic acid and several lytic enzymes. Current Microbiology 59: 608615.

Kramer, R.F., S. Freytag and E. Schmelzer. 1997. In vitro formation of infection structures of Phytophthora infestans is associated with synthesis of stage specific polypeptides. European Journal of Plant Pathology 103: 43-53.

Lee, J.Y., S.S. Moon and B.K. Hwang. 2003. Isolation and antifungal and antioomycete activities of aerugine produced by Pseudomonas ûuorescens strain MMB16. Applied and Environmental Microbiology 69: 2023-2031.

Lee, Y.K., J.S. Kim, B.I. Jang, Y.S. Jang and H.Y. Lee. 2003. Biological control of Pythium root rot by radiation induced mutant of Bacillus lentimorbus WJ5a17. Korean Journal of Environmental Biology 21: 276285.

Lee, Y.K., M. Senthilkumar, J.H. Kim, K. Swarnalakshmi and K. Annapurna. 2008. Puriûcation and partial characterization of antifungal metabolite from Paenibacillus lentimorbus WJ5. World Journal of Microbiology and Biotechnology 24: 3057-3062.

Lee, J.Y., J.Y. Lee, S.S. Moon and B.K. Hwang. 2005. Isolation and Antifungal Activity of 4-Phenyl-3Butenoic Acid from Streptomyces koyangensis Strain VK-A60. Journal of Agriculture and Food Chemistry 53: 7696-7700.

Li, B., S. Ravnskov, G.Xie and J. Larsen. 2007. Biocontrol of Pythium damping-off in cucumber by arbuscular mycorrhiza-associated bacteria from the genus Paenibacillus. Biocontrol 52: 863-875.

Lutz, M.P., V. Michel, C. Martinez and C. Camps. 2012. Lactic acid bacteria as biocontrol agents of soil-borne pathogens. Biological Control of Fungal and Bacterial Plant Pathogens IOBC-WPRS Bulletin. 78: 285-288.

Maleki, M., S. Mostafaee, L. Mokhtarnejad and M. Farzaneh. 2010. Characterization of Pseudomonas fluorescens strain CV6 isolated from cucumber rhizosphere in Varamin as a potential biocontrol agent. Australian Journal of Crop Science 4: 676-683.

Maleki, M., L. Mokhtarnejad and S. Mostafaee. 2011. Screening of rhizobacteria for biological control of cucumber root and crown rot caused by Phytophthora drechsleri. Plant Pathology Journal. 27: 78-84.

Margulis, L., M.F. Dolan and R. Guerrero. 2000. The chimeric eukaryote: origin of the nucleus from the karyomastigont in amitochondriate protists.
Proceedings of the National Academy of Sciences. USA,. pp.6954-6959.

Margulis, L. and K.V. Schwartz. 2000. Five kingdoms: An illustrated guide to the phyla of life on earth. W.H. Freeman \& Co., New York.

Maurhofer, M., C. Keel, D. Haas and G. Defago. 1994. Pyoluteorin production by Pseudomonas fluorescens strain CHA0 is involved in the suppression of Pythium damping-off of cress but not of cucumber. European Journal of Plant Pathology 100: 221-232.

Mavrodi, O.V., N. Walter, S. Elateek, C.G. Taylor and P.A. Okubara. 2012. Suppression of Rhizoctonia and Pythium root rot of wheat by new strains of Pseudomonas. Biological Control 62: 93-102.

McGregor, A.J. 1983. Experiments on the profitability of chemical black pod control in Papua New Guinea. Tropical Pest Management 29: 129-136.

McGregor, A.J. 1984. Comparison of cuprous oxide and metalaxyl with mixtures of these fungicides for the control of Phytophthora pod rot of cocoa. Plant Pathology 33: 81-87.

Mezaache, S., A. Guechi, M.M. Zerroug, R.N. Strange and J. Nicklin. 2010. Antifungal activity of rhizospheric bacteria. Communications in Agricultural and Applied Biological Sciences 75: 671-674.

Mirzaee, M.R., M. Abbasi and M. Mohammadi. 2009. Albugo candida causing white rust on Erysimum crassicaule in Iran. Australasian Plant Disease Notes 4: 124-125.

Moller, K., B. Jensen, H. Paludson Andersen, H. Stryhn and J. Hockenhull. 2003. Biocontrol of Pythium tracheiphilum in Chinese cabbage by Clonostachys rosea under field conditions. Biocontrol Science and Technology 13: $171-182$.

Moorman, G.W. and S.H. Kim. 2004. Species of Pythium from greenhouses in Pennsylvania exhibit resistance to propamocarb and mefenoxam. Plant Disease 88: 630632.

Muthukumar, A., A. Eswaran and G. Sangeetha. 2011. Induction of systemic resistance by mixtures of fungal and endophytic bacterial isolates against Pythium aphanidermatum. Acta physiologiae Plantarum 33: 19331944.

Nelson, E.B. 1988. Biological control of Pythium seed rot and pre-emergence damping-off of cotton with Enterobacter cloacae and Erwinia herbicola applied as seed treatments. Plant Disease 72: 140-142.

Nelson, E.B. 2004. Biological control of oomycetes and fungal pathogens. In: Encyclopedia of Plant and Crop Science (Ed. R.M. Goodman). Marcel Decker, USA, pp. 137140.

Nguyen, X.H., K.W. Naing, Y.S. Lee, H. Tindwa, G.H. Lee, B.K. Jeong, H.M. Ro, S.J. Kim, W.J. Jung and K.Y. Kim. 2012. Biocontrol potential of Streptomyces griseus H7602 against root rot disease (Phytophthora capsici) in Pepper. Plant Pathology Journal 28: 282-289. 
Pal, K.K. and B.M. Gardener. 2006. Biological Control of Plant Pathogens. Plant Health Instructor. pp. 1-25. Available via APSnet DOI: 10.1094/PHI-A-2006-1117-02 .

Parke, J.L., R.E. R, A.E. Joy and E.B. King. 1991. Biological control of Pythium damping-off and Aphanomyces root rot of peas by application of Pseudomonas cepacia or $P$. fluoresces to seed. Plant Disease 75: 987-992.

Parra, G. and J.B. Ristaino. 2001. Resistance to mefenoxam and metalaxyl among field isolates of Phytophthora capsici causing Phytophthora blight of bell pepper. Plant Disease 85: 1069-1075.

Ramarethinam, S., N.V. Murugesan and S. Marimuthu. 2008. Efficacy of Cheatomium globosum (Symbion C) against late blight of potato caused by Phytophthora infestans. Pestology 32: 14-18.

Rost, C. and M. Thines. 2012. A new species of Pustula (Oomycetes, $\mathrm{v} \quad$ Albuginales) is the causal agent of sunflower white rust. Mycological Progress 11: 351359 .

Sang, M.K., M.H. Chiang, E.S. Yi, K.W. Park and K.D. Kim. 2006. Biocontrol of Korean Ginseng root rot caused by Phytopthora cactorum using antagonsitic bacterial strains ISE13 and KJ1R5. Plant Pathology Journal 22: 103-106.

Sang, M.K., J.Y. Oh and K.D. Kim. 2007. Root-dipping application of antagonisitc rhizobacteria for the control of Phytopthora blight of pepper under field conditions. Plant Pathology Journal 29: 109-112.

Sang, M.K., S.C. Chun and K.D. Kim. 2008. Biological control of Phytophthora blight of pepper by antagonistic rhizobacteria selected from a sequential screening procedure. Biological Control 46: 424-433.

Sang, M.K. and K.D Kim. 2012. The volatile-producing Flavobacterium johnsoniae strain GSE09 shows biocontrol activity against Phytophthora capsici in pepper. Journal of Applied Microbiology 13: 383-398.

Sang, M.K., A. Shrestha, D.Y. Kim, K. Park, C.H. Pak and K.D. Kim. 2013. Biocontrol of Phytophthora blight and anthracnose in pepper by sequentially selected antagonistic rhizobacteria against Phytophthora capsici. Plant Pathology Journal 29: 154-167.

Sanogo, S. and P. Ji. 2012. Integrated management of Phytophthora capsici on solanaceous and cucurbitaceous crops: current status, gaps in knowledge and research needs. Canadian Journal of Plant Pathology 34: 479-492.

Schmitthenner, A.F.1985. Problems and progress in control of Phytophthora root rot of soybean. Plant Disease 69: 362-368.

Serrano, Y.G., M.L. Guirado, M.P. Carmona and J. Gómez. 2008. First report of root and crown necrosis of bean caused by Pythium aphanidermatum in Spain. Plant Disease 92: 174.

Shen, S.S., O.H. Choi, S.M. Lee and C.S. Park. 2002. In vitro and in vivo activities of a biocontrol agent, Serratia plymuthica A21-4, against Phytophthora capsici. Plant Pathology Journal 18: 221"224.
Son, S.W., H.Y. Kim, G.J. Choi, H.K. Lim, K.S. Jang, S.O. Lee, S. Lee, N.D. Sung and J.C. Kim. 2008. Bikaverin and fusaric acid from Fusarium oxysporum show antioomycete activity against Phytophthora infestans. Journal of Applied Microbiology 104: 692-698.

Souli, M., N. Boughalleb, P. Abad-Campos, A.A. lvarez, Luis A. Pe'rez-Sierra, J. Armengol and J. García-Jiménez. 2011. First Report of Pythium indigoferae and P. irregular associated to apple trees decline in Tunisia. Journal of Phytopathology 159: 352-357.

Sudisha, J. and H.S. Shetty. 2009. Anti-oomycete compounds from Ganoderma appalantum, a wood rot basidiomycete. Natural Product Research 23: 737-753.

Timmusk, S., P. van West, N.A.R. Gow and R. Paul Huffstutler. 2009. Paenibacillus polymyxa antagonizes oomycete plant pathogens Phytophthora palmivora and Pythium aphanidermatum. Journal of Applied Microbiology 106:1473-1481.

Titone, P., M. Mocioni, A. Garibaldi and M.L. Gullino. 2009. Fungicide failure to control Pythium blight on turf grass in Italy. Journal of Plant Disease and Protection 116: 55 59.

Tomioka, K., T. Takehara, H. Osaki, H. Sekiguchi, K. Nomiyama and K. Kageyama. 2013. Damping-off of soybean caused by Pythium myriotylum in Japan. Journal of General Plant Pathology 79: 162-164.

Tyler, B.M. 2007. Phytophthora sojae: root-rot pathogen of soybean and model oomycete. Molecular Plant Pathology 8:1-8.

Tyler, B.M. 2011. Entry of oomycete and fungal effectors into host cells. in: Effectors in Plant-Microbe Interactions. Wiley-Blackwell, Oxford.

Van Dijk, K.V. and E. Nelson. 2000. Fatty acid competition as a mechanism by which Enterobacter cloacae suppresses Pythium ultimum sporangium germination and dampingoff. Applied and environmental microbiology 66: 53405347.

Van West, P., A.A. Appiah and N.A.R. Gow. 2003. Advances in research on oomycete root pathogens. Physiological and Molecular Plant Pathology 62: 99-113.

Williams, G.E. and M.J.C. Asher. 1996. Selection of rhizobacteria for the control of Pythium ultimum and Aphanomyces cochlioides on sugarbeet seedlings. Crop Protection 15: 479-486.

Winter, G. 1880. Rabenhorst's Kryptogamen-Flora, PilzeSchizomyceten, Saccharomyceten und Basidiomyceten. Vol. 1. 2nd ed. Kummer, Leipzig, Germany. 80 pp.

Wynn, A.R. and H.A.S. Epton. 1979. Parasitism of oospores of Phytopthora erythroseptica in soil. Transactions of the British Mycological Society 73: 255-259.

Yang, Y., K.F. Chang, S.F. Hwang, N.W. Callan, R.J. Howard and S.F. Blade. 2004. Biological control of Pythium damping-off in Echinacea angustifolia with Trichoderma species. Journal of Plant Disease and Protection 111: 126-1. 